\title{
PENGARUH KOMPOSISI MEDIA TANAM TERHADAP PERTUMBUHAN DAN HASIL TANAMAN BUNGA GLADIOL (Gladiolus hybridus L.)
}

\section{EFFECT OF PLANTING MEDIA COMPOSITION ON THE GROWTH AND YIELD OF GLADIOLUS (Gladiolus hybridus L.) FLOWER PLANTS}

\author{
Eftrida Yuliana $^{1}$, Nugraheni Widyawati ${ }^{1}$, Alfred Jansen Sutrisno ${ }^{1}$ \\ ${ }^{1}$ Program Studi Agroteknologi, Fakultas Pertanian dan Bisnis, Universitas Kristen Satya Wacana \\ ${ }^{\square}$ Komunikasi Penulis, email: eftrida28@gmail.com \\ DOI:http://dx.doi.org/10.23960/jtep-lv9i4.353-360 \\ Naskah ini diterima pada 3 November 2020; revisi pada 14 Desember 2020; \\ disetujui untuk dipublikasikan pada 16 Desember 2020
}

\begin{abstract}
The purpose of this study was to determine the effect of media composition on the growth and yield of Gladiolus flowers and to determine the composition that best supports the growth and yield of the flowers. The study was conducted through experiments using a Randomized Block Design (RBD), with 7 treatments of the media composition namely P1 (soil), P2 (soil:husk charcoal 1:1), P3 (soil:husk charcoal 1:2), P4 (soil:husk charcoal 2:1), P5 (soil:cocopeat 1:1), P6 (soil:cocopeat 1:2), P7 (soil:cocopeat 2:1).Each treatment is in each group which amounts to 4 groups. Media composition was observed through physical and chemical parameters of $p H$, water content, and available NPK. Plant growth was observed through the parameters of plant height and number of leaves. Yield of plants was observed through the parameters of the number of flowers and flower diameter. The results showed that the composition of the planting medium did not affect plant height and number of leaves, but influenced the number of flowers and flower diameter. The planting medium that gives the best results is soil (P1).
\end{abstract}

Keywords: cocopeat, gladiol, husk charcoal

\begin{abstract}
ABSTRAK
Tujuan penelitian ini adalah untuk mengetahui pengaruh komposisi media tanam terhadap pertumbuhan dan hasil bunga Gladiol serta menentukan komposisi yang paling baik dalam mendukung pertumbuhan dan perolehan hasil bunga. Penelitian dilakukan melalui percobaan menggunakan Rancangan Acak Kelompok (RAK), dengan 7 perlakuan komposisi media tanam yaitu P1 (tanah), P2 (tanah : arang sekam 1:1), P3 (tanah : arang sekam 1:2), P4 (tanah : arang sekam 2:1), P5 (tanah : cocopeat 1:1), P6 (tanah : cocopeat 1:2), P7 (tanah : cocopeat 2:1). Masing masing perlakuan ada dalam setiap kelompok yang sekaligus sebagai ulangan yang berjumlah 4 kelompok. Parameter yang diamati meliputi parameter fisik dan kimia media tanam yang terdiri dari $\mathrm{pH}$, kadar air, dan NPK tersedia. Parameter pertumbuhan tanaman diamati melalui parameter tinggi tanaman dan jumlah daun serta hasil tanaman diamati melalui parameter jumlah bunga dan diameter bunga. Hasil penelitian menunjukkan bahwa komposisi media tanam tidak mempengaruhi tinggi tanaman dan jumlah daun, tetapi mempengaruhi jumlah bunga dan diameter bunga. Media tanam yang memberikan hasil terbaik adalah media tanah (P1) dengan jumlah bunga sebanyak 11.67 kuntum dan diameter bunga sebesar $13.62 \mathrm{~cm}$.
\end{abstract}

Kata Kunci: arang sekam, cocopeat, gladiol

\section{PENDAHULUAN}

Gladiol (Gladiolus hybridus L.) adalah tanaman hias bunga yang memiliki bentuk daun sempit dan panjang seperti pedang. Gladiol memiliki ukuran bunga yang cukup besar dan beraneka macam warnanya. Selain sebagai bunga taman, gladiol juga digunakan sebagai bunga potong.
Tanaman gladiol merupakan salah satu jenis penghasil bunga potong yang berpotensi untuk dikembangkan karena bunganya dapat bertahan 5-10 hari dan dapat dibudidaya sepanjang tahun (Badriah, 2007).

Menurut Direktorat Jenderal Hortikultura (2015) hasil produksi gladiol dari tahun 2010 
hingga tahun 2014 terus mengalami penurunan yang cukup besar, dimana pada tahun 2014 produksi bunga potong gladiol hanya mencapai 1.884.719 tangkai, sedangkan permintaan bunga potong gladiol sekitar 6 juta tangkai per tahun (Balitbang Pertanian, 2014). Keunggulan dari tanaman Gladiol membuat permintaan akan bunga gladiol cukup tinggi, namun hasil produksi tidak dapat memenuhi permintaan tersebut sehingga dibutuhkan upaya meningkatkan produksi tanaman gladiol. Salah satu cara yang dapat ditempuh adalah meningkatkan luas penanaman melalui budidaya tanaman gladiol dalam polybag.

Budidaya gladiol di polybag dapat menghemat lahan, perawatan tanaman lebih mudah, menghemat pemakaian air, nutrisi yang diberikan dapat langsung diserap akar tanaman dan tanaman mudah dipindahkan ke berbagai tempat. Umumnya gladiol di budidaya menggunakan media tanam tanah, tetapi bentuk polybag dan partikel tanah yang cukup berat membuat tanah mudah memadat kebawah, hal tersebut menyebabkan ruang udara menjadi berkurang sehingga tanaman akan kekurangan oksigen dan air juga tidak terserap sampai kebawah media yang mengakibatkan akar menjadi kekurangan air. Maka dari itu, diperlukan media tanam lainnya untuk dicampurkan dengan tanah.

Hasil penelitian Laing et al. (2012) pada budidaya gladiol menggunakan variasi media menunjukkan bahwa variasi media tanam tersebut mempengaruhi semua parameter yang diamati dan media tanam yang paling baik adalah tanah saja, sedangkan penelitian yang dilakukan oleh Jabbar et al.(2018) budidaya Gladiol menggunakan perlite dan cocopeat dengan rasio 1:1, 3:1, dan 1:3 secara signifikan mempengaruhi parameter vegetatif dan jumlah bunga dengan hasil terbaik didapat dari media perlite dan cocopeat dengan rasio 1:3.

Tanah sebagai media tanam yang dicampurkan dengan arang sekam dapat memperbaiki poripori media tanam sehingga baik untuk respirasi akar, dapat mempertahankan kelembaban media karena arang sekam dapat mengikat air, dimana air tersebut dilepaskan ke pori mikro untuk diserap oleh tanaman dan mendorong pertumbuhan mikroorganisme yang berguna bagi tanah dan tanaman (Kusmarwiyah dan Sri, 2011). Arang sekam memiliki pori yang lebih besar maka daya serap yang dihasilkan pun tinggi, hal ini membuat arang sekam mampu menyerap dan menyimpan unsur hara dengan baik (Agustin et al., 2014).

Cocopeat dapat digunakan sebagai media tumbuh atau campuran media tumbuh, karena cocopeat memiliki kelebihan yaitu memiliki pori-pori yang dapat menyerap dan menyimpan air dalam jumlah yang banyak sehingga tidak memerlukan intensitas penyiraman yang tinggi. Pada umumnya cocopeat memiliki kapasitas menahan air cukup tinggi sehingga ketersediaan air juga tinggi serta sifat cocopeat yang tidak terlalu padat sehingga sirkulasi udara di dalam media baik untuk akar tanaman (Istomo dan Valentino, 2012). Tujuan dari penelitian ini adalah mengetahui pengaruh komposisi media tanam terhadap pertumbuhan dan hasil bunga Gladiol dan menentukan komposisi media tanam yang mendukung pertumbuhan dan perolehan hasil bunga terbaik.

\section{BAHAN DAN METODE}

Penelitian ini dilakukan pada bulan Juni sampai November 2019 di kebun percobaan Salaran Fakultas Pertanian dan Bisnis Universitas Kristen Satya Wacana dengan ketinggian tempat \pm 1050 mdpl. Rancangan yang digunakan dalam penelitian ini adalah RAK (Rancangan Acak Kelompok) dengan 7 perlakuan dan 4 kelompok yang sekaligus sebagai ulangan. Perlakuan tersebut terdiri dari P1 (tanah), P2 (tanah : arang sekam 1:1), P3 (tanah : arang sekam 1:2), P4 (tanah : arang sekam 2:1), P5 (tanah : cocopeat 1:1), P6 (tanah : cocopeat 1:2), P7 (tanah : cocopeat 2:1) dan setiap perlakuan diulang sebanyak 4 kali. Bahan yang digunakan dalam penelitian ini adalah tanah, arang sekam, cocopeat, polybag ukuran 30 × $40 \mathrm{~cm}$, umbi gladiol, pupuk urea, pupuk TSP, pupuk KCL, dan air. Alat yang digunakan dalam penelitian ini adalah cangkul, ember, timbangan, jangka sorong, dan alat lainnya yang mendukung penelitian ini. 
Pelaksanaan penelitian dimulai dari persiapan lahan dengan pemberian tanda pada lokasi lahan yang digunakan lalu dibersihkan dari gulma dan diratakan. Selanjutnya dilakukan persiapan media tanam yang diawali dengan sterilisasi cocopeat untuk mengurangi senyawa zat tannin pada cocopeat dengan cara di rendam dengan air selama satu hari kemudian dijemur hingga cukup kering, penggemburan tanah dengan cara dicangkul dan menempatkan arang sekam dalam satu wadah lalu mencampurkan media tanam dengan perbandingan yang sudah ditentukan lalu dimasukkan ke dalam polybag. Setelah itu media tanam disiram terlebih dahulu dan dilakukan penanaman umbi gladiol. Penyiraman tanaman dilakukan setiap hari atau menyesuaikan kondisi cuaca. Pemberian pupuk urea dan pupuk TSP (Triple Super Phosphate) masing-masing sebanyak 5 gram per polybag pada saat munculnya daun ke 2 atau sekitar 20 hst dan pemberian pupuk urea dan KCL masing-masing 5 gram per polybag pada saat primordial bunga muncul atau sekitar 60 hst. Pemeliharaan tanaman meliputi penyiangan gulma yang dilakukan seminggu sekali secara manual dengan cara mencabut gulma yang ada di sekitar tanaman di dalam polybag, serta pengendalian hama yang juga dilakukan secara manual.
Parameter fisik dan kimia media tanam yang diamati meliputi pH, kadar air, dan NPK tersedia. Sampel media tanam yang diambil adalah sampel media tanam awal setelah media tanam dicampurkan sesuai dengan perbandingan yang ditentukan dan media tanam akhir. Sebelum di analisis, sampel media tanam dikering anginkan terlebih dahulu. $\mathrm{pH}$ yang diukur adalah $\mathrm{pH}$ aktual $\left(\mathrm{pH} \mathrm{H}_{2} \mathrm{O}\right)$, dan metode yang digunakan untuk kandungan $\mathrm{N}$ tersedia adalah metode Rajendra Prasad, untuk P tersedia adalah metode Bray 2, dan penetapan $\mathrm{K}$ tersedia dilakukan dengan analisis kalium yang larut dalam air dan diukur dengan Flame Photometer.

Parameter pertumbuhan tanaman yang diamati meliputi tinggi tanaman $(\mathrm{cm})$ dan jumlah daun (helai) pada 20, 40, dan 60 HST (hari setelah tanam). Parameter kualitas bunga yang diamati meliputi jumlah bunga (kuntum) dan diameter bunga $(\mathrm{cm})$. Jumlah sampel masing-masing parameter pengamatan adalah 12 tanaman. Data pengamatan yang diperoleh dari penelitian ini dianalisis dengan menggunakan analisis sidik ragam (uji F) pada taraf 5\%. Apabila hasil uji F menunjukkan berpengaruh nyata maka dilanjutkan dengan uji Beda Nyata Jujur (BNJ) selang kepercayaan 95\%.

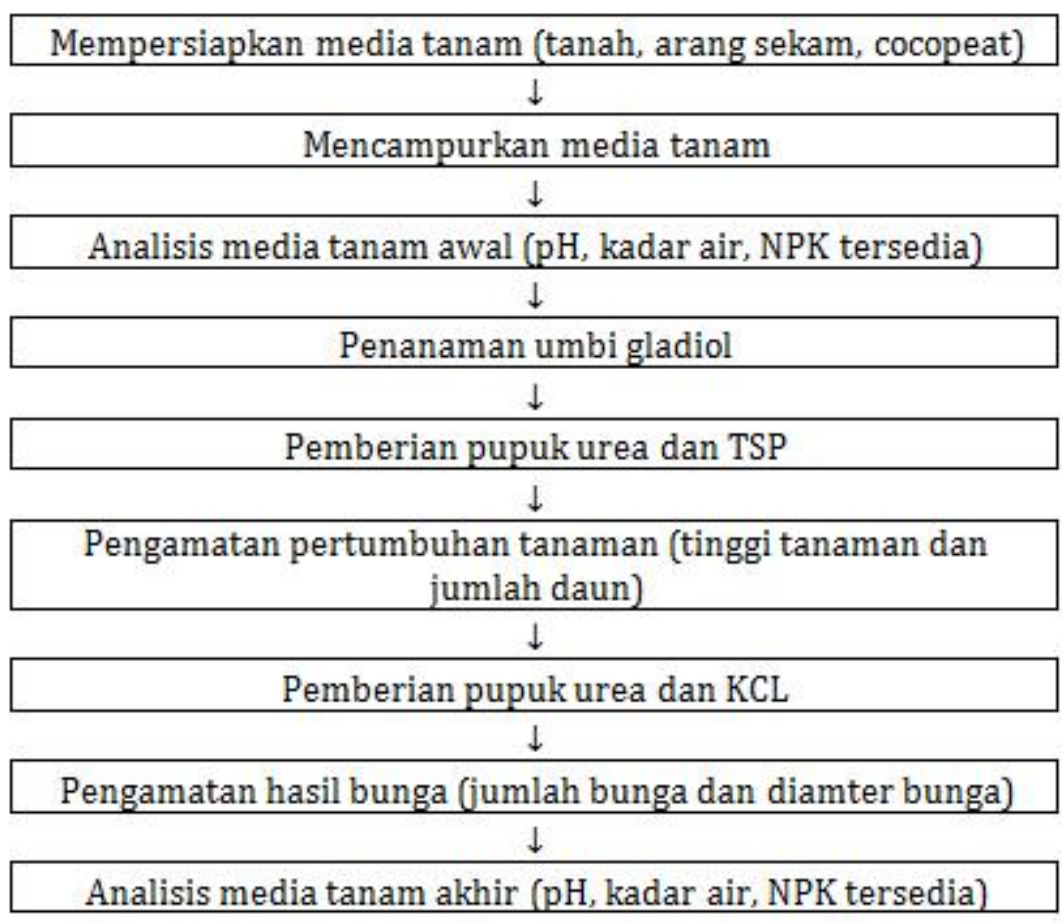

Gambar 1. Diagram Alir Tahapan Penelitian 


\section{HASIL DAN PEMBAHASAN}

\subsection{Analisis karakter Kimiawi Media Tanam}

Analisis karakter kimiawi media tanam awal dilakukan untuk mengetahui kandungan hara yang ada pada setiap komposisi media tanam. Hasil analisis pH, dan kadar unsur hara media tanam disajikan dalam Tabel 1.

Hasil analisis media tanam awal pada Tabel 1 menunjukkan bahwa seluruh perlakuan memiliki kriteria $\mathrm{pH}$ yang agak masam. $\mathrm{N}$ tersedia dan $P$ tersedia pada seluruh perlakuan memiliki kriteria sangat rendah. Kandungan $\mathrm{K}$ tersedia pada P1 sangat rendah, P6 sedang dan perlakuan lainnya berada pada kriteria rendah. Untuk hasil media tanam akhir pada Tabel 2 menunjukkan bahwa seluruh perlakuan memiliki kriteria yang agak masam. $\mathrm{N}$ tersedia dan $P$ tersedia pada seluruh perlakuan memiliki kriteria sangat rendah dan $\mathrm{K}$ tersedia pada seluruh perlakuan memiliki kriteria rendah.
Menurut Badriah (2007), tanaman gladiol sangat toleran pada semua kondisi media tanam asalkan media tanam tersebut memiliki drainase yang baik agar akar tidak rusak dan faktor utama yang mempengaruhi pertumbuhan dan perkembangan tanaman gladiol adalah suhu, kelembaban dan yang paling penting adalah cahaya karena gladiol membutuhkan sinar matahari penuh.

\subsection{Pengaruh Komposisi Media Tanam Terhadap Pertumbuhan Tanaman Gladiol (Tinggi Tanaman dan Jumlah Daun)}

Hasil analisis data lanjutan menggunakan uji analisis statistik sidik ragam 5\% ditampilkan pada Gambar 2. dan didapatkan hasil bahwa komposisi media tanam tidak berpengaruh nyata terhadap tinggi tanaman pada $20 \mathrm{HST}, 40 \mathrm{HST}$, maupun 60 HST. Penelitian yang dilakukan oleh Laing et al (2012) menggunakan campuran media tanam memberikan pengaruh nyata terhadap tinggi tanamannya karena setiap

Tabel 1. Kadar Air, Kadar Unsur Nitrogen, Fosfor, Kalium dan Nilai pH Berbagai Komposisi Media Tanam Awal

\begin{tabular}{lcccccc}
\hline Komposisi Media Tanam & $\mathbf{p H}$ & $\begin{array}{c}\text { Kadar } \\
\text { Air }\end{array}$ & $\begin{array}{c}\mathbf{N H}_{\mathbf{4}} \\
\text { (ppm) }\end{array}$ & $\begin{array}{c}\mathbf{N O}_{3} \\
\text { (ppm) }\end{array}$ & $\begin{array}{c}\mathbf{P} \\
\text { Tersedia } \\
\text { (ppm) }\end{array}$ & $\begin{array}{c}\mathbf{K} \\
\text { Tersedia } \\
\text { (ppm) }\end{array}$ \\
\hline P1 (tanah) & 5,68 & $21,95 \%$ & 0,023 & 0,032 & 0,184 & 9,80 \\
P2 (tanah : arang sekam 1:1) & 5,53 & $19,05 \%$ & 0,027 & 0,041 & 0,207 & 13,36 \\
P3 (tanah : arang sekam 1:2) & 5,57 & $18,48 \%$ & 0,036 & 0,045 & 0,209 & 13,88 \\
P4 (tanah : arang sekam 2:1) & 5,49 & $21,65 \%$ & 0,027 & 0,036 & 0,197 & 11,75 \\
P5 (tanah : cocopeat 1:1) & 6,15 & $23,46 \%$ & 0,059 & 0,054 & 0,225 & 15,77 \\
P6 (tanah : cocopeat 1:2) & 6,04 & $26,26 \%$ & 0,077 & 0,059 & 0,229 & 22,18 \\
P7 (tanah : cocopeat 2:1) & 6,07 & $22,85 \%$ & 0,041 & 0,050 & 0,223 & 14,38 \\
\hline
\end{tabular}

Keterangan: Standar harkat tanah sesuai dengan Balittanah (2009).

Tabel 2. Kadar Air, Kadar Unsur Nitrogen, Fosfor, Kalium dan Nilai pH Berbagai Komposisi Media Tanam Akhir

\begin{tabular}{lcccccc}
\hline Komposisi Media Tanam & $\mathbf{p H}$ & $\begin{array}{c}\text { Kadar } \\
\text { Air }\end{array}$ & $\begin{array}{c}\mathbf{N H}_{\mathbf{4}} \\
\mathbf{( p p m )}\end{array}$ & $\begin{array}{c}\mathbf{N O}_{3} \\
\mathbf{( p p m )}\end{array}$ & $\begin{array}{c}\mathbf{P} \\
\text { Tersedia } \\
\text { (ppm) }\end{array}$ & $\begin{array}{c}\text { K } \\
\text { Tersedia } \\
\text { (ppm) }\end{array}$ \\
\hline P1 (tanah) & 5,1 & $26,58 \%$ & 0,027 & 0,027 & 0,220 & 10,34 \\
P2 (tanah : arang sekam 1:1) & 5,04 & $24,075 \%$ & 0,036 & 0,036 & 0,227 & 11,50 \\
P3 (tanah : arang sekam 1:2) & 5,05 & $23,15 \%$ & 0,040 & 0,040 & 0,233 & 12,05 \\
P4 (tanah : arang sekam 2:1) & 5,13 & $24,69 \%$ & 0,031 & 0,031 & 0,223 & 11,42 \\
P5 (tanah : cocopeat 1:1) & 5,24 & $30,21 \%$ & 0,049 & 0,054 & 0,257 & 12,60 \\
P6 (tanah : cocopeat 1:2) & 5,12 & $35,87 \%$ & 0,054 & 0,063 & 0,278 & 12,64 \\
P7 (tanah : cocopeat 2:1) & 5.18 & $29,53 \%$ & 0,045 & 0,045 & 0,245 & 12,07 \\
\hline
\end{tabular}

Keterangan: Standar harkat tanah sesuai dengan Balittanah (2009). 
perlakuannya memiliki kandungan bahan organik yang berbeda-beda dilihat dari sifat media tanamnya yang sangat berbeda yaitu sekam dan pasir sehingga hasil dari penelitian beliau memberikan hasil yang berbeda nyata.

Pertumbuhan tinggi tanaman gladiol terjadi karena adanya pemanjangan daun yang disebabkan oleh adanya pembelahan dan pertambahan ukuran sel-sel pada jaringan meristem tersebut. Proses pertambahan dan pembesaran sel tersebut membutuhkan unsur hara nitrogen $(\mathrm{N})$ karena menurut Harjadi (2002) nitrogen dapat membentuk klorofil, protein, lemak, karbohidrat serta membantu proses asimilasi dan respirasi tanaman sehingga proses fotosintesis dan metabolisme dapat berlangsung dengan baik.

Komposisi media tanam tidak berpengaruh nyata terhadap tinggi tanaman dikarenakan kandungan unsur nitrogen $(\mathrm{N})$ pada semua perlakuan pada media tanam awal dan akhir memiliki kriteria yang sangat rendah, sehingga tinggi tanaman dari setiap perlakuan pun akan sama atau tidak berbeda nyata.

Dengan bertambahnya waktu, proses pembelahan dan pertambahan ukuran sel terus terjadi secara perlahan sehingga ukuran tinggi tanaman meningkat seiring dengan bertambahnya umur tanaman. Namun, jika diperbandingkan antar perlakuan komposisi media tanam, ternyata tidak ada perbedaan yang nyata dalam proses pertumbuhan tinggi tanaman. Diduga hal ini disebabkan karena tanaman masih memperoleh sumber daya lingkungan yang relatif sama, walaupun komposisi media tanamnya berbeda. Sumber daya lingkungan itu adalah suhu, kelembaban, pupuk, dan air.

Salah satu faktor penting yang memepengaruhi pertumbuhan tanaman adalah varietas tanaman. Semua subang (bibit berbentuk umbi) berasal dari satu varietas yang sama yaitu verietas Anisa, maka dari itu tinggi tanaman yang dihasilkan pun tidak berbeda nyata. Menurut Hermiati (2000) menyatakan bahwa setiap varietas memiliki perbedaan dalam hal kemampuannya untuk mempertahankan hidup dan pertumbuhan individu dari iklim yang berbeda. Faktor genetik tanaman dan adaptasinya terhadap lingkungan menghasilkan pertumbuhan yang berbeda-beda. Tanaman dengan varietas yang sama berarti memiliki faktor genetik dan cara beradaptasi yang sama pula.

Hasil analisis sidik ragam pada taraf nyata $5 \%$ didapatkan bahwa perlakuan media tanam tidak berpengaruh nyata terhadap jumlah daun pada 20 HST, 40 HST, maupun 60 HST. Penelitian yang dilakukan oleh Laing dkk (2012) menggunakan campuran media tanam memberikan pengaruh nyata terhadap daunnya karena setiap perlakuannya memiliki kandungan bahan organik yang berbeda-beda dilihat dari sifat media tanamnya yang sangat berbeda yaitu sekam dan pasir sehingga hasil dari penelitian beliau memberikan hasil yang berbeda nyata.

Pertambahan jumlah daun terjadi melalui proses diferensiasi sel-sel pada bagian apikal tanaman. Proses tersebut dikendalikan oleh fospor (P). Menurut Malik (2015) Fosfor (P) merupakan

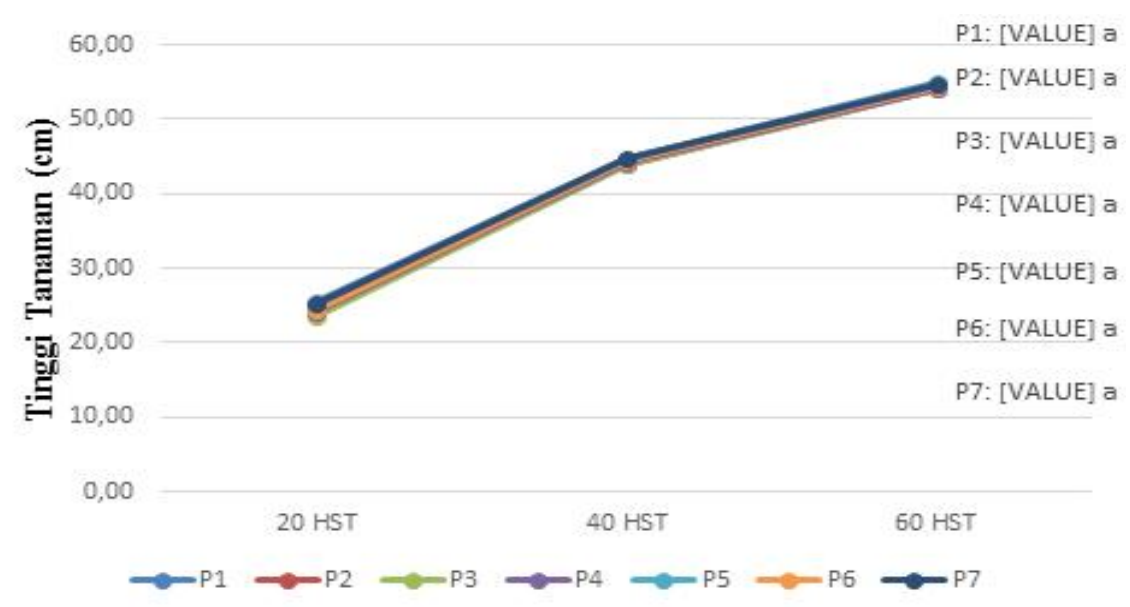

Gambar 2. Tinggi Tanaman Gladiol pada Berbagai Komposisi Media Tanam 
senyawa penting dalam sel-sel tanaman karena pertumbuhan daun menunjukkan adanya penambahan isi sel, sel terus membelah dan mengalami diferensiasi menjadi jaringan dan organ.

Hasil analisis menunjukkan bahwa komposisi media tanam tidak menyebabkan perbedaan yang nyata dalam jumlah daun tanaman gladiol karena P tersedia pada seluruh komposisi media tanam awal dan akhir memiliki kriteria yang sama yaitu sangat rendah sehingga proses diferensiasi sel-nya pun sama. Hal ini menunjukkan bahwa komposisi media tanam yang diuji tidak menyebabkan penghambatan terhadap pertambahan jumlah daun tanaman gladiol.

\subsection{Pengaruh Komposisi Media Tanam Terhadap Jumlah Bunga dan Diameter Bunga}

Hasil analisis sidik ragam pada taraf nyata $5 \%$ didapatkan bahwa komposisi media tanam berpengaruh nyata terhadap jumlah bunga dan diameter bunga. Perlakuan media tanam yang menghasilkan tanaman dengan jumlah bunga terbanyak adalah P1 (tanah) dengan jumlah bunga 11,67 kuntum dan tanaman dengan jumlah bunga terendah didapat dari P3 (tanah : arang sekam perbandingan 1:2) dengan jumlah bunga 10 kuntum. Dari hasil analisis sidik ragam pada taraf nyata $5 \%$ didapatkan bahwa perlakuan media tanam berpengaruh nyata terhadap diamter bunga. Perlakuan media tanam yang menghasilkan tanaman dengan diameter bunga terbesar adalah P1 (tanah) dengan diameter bunganya adalah $13,62 \mathrm{~cm}$ dan tanaman dengan diameter bunga terkecil didapat dari P3 (tanah : arang sekam perbandingan 1:2) dengan diameter bunga $13,03 \mathrm{~cm}$.

Tabel 2 menunjukkan bahwa komposisi media tanam memberikan hasil yang berbeda nyata terhadap jumlah bunga dan diameter bunga. Hal tersebut terjadi karena proses penyerapan unsur hara pada media tanam dari setiap tanaman relatif seimbang yang dimana pada saat tanaman berumur 60 hari setelah tanam kondisi akar

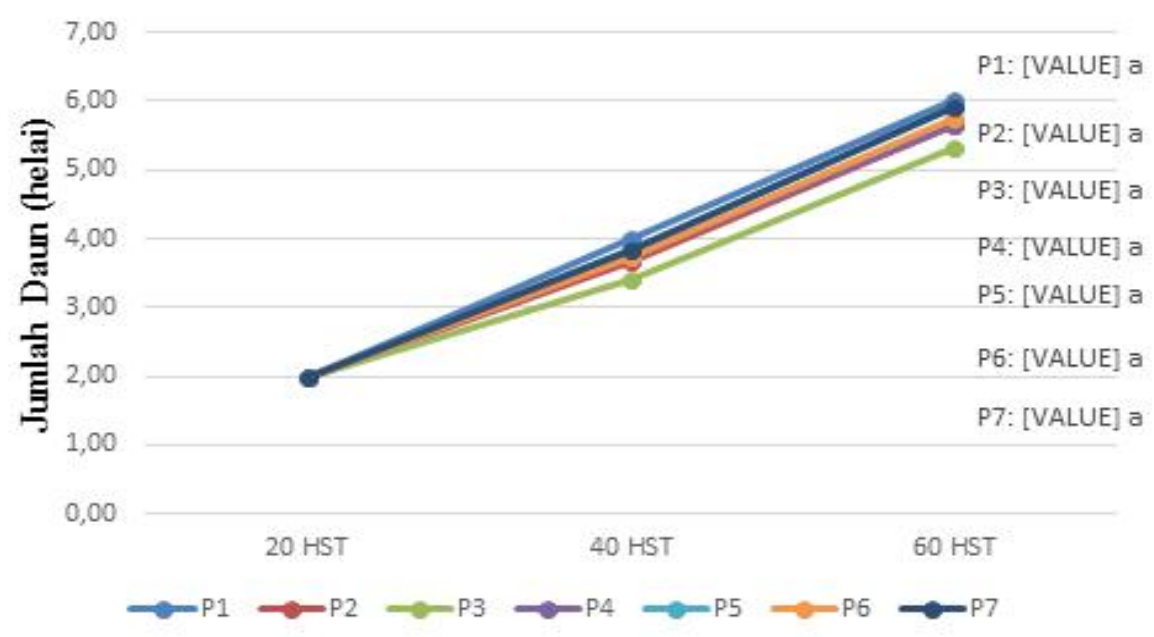

Gambar 3. Jumlah Daun Tanaman Gladiol pada Berbagai Komposisi Media Tanam

Tabel 3. Jumlah dan Diameter Bunga

\begin{tabular}{lcc}
\hline \multicolumn{1}{c}{ Komposisi Media Tanam } & Jumlah Bunga (kuntum) & Diameter Bunga (cm) \\
\hline P3 (tanah : arang sekam 1:2) & $10,00 \mathrm{a}$ & $13,03 \mathrm{a}$ \\
P2 (tanah : arang sekam 1:1) & $10,58 \mathrm{ab}$ & $13,20 \mathrm{a}$ \\
P4 (tanah : arang sekam 2:1) & $10,67 \mathrm{ab}$ & $13,28 \mathrm{ab}$ \\
P6 (tanah : cocopeat 1:2) & $10,83 \mathrm{~b}$ & $13,56 \mathrm{~b}$ \\
P5 (tanah : cocopeat 1:1) & $10,92 \mathrm{~b}$ & $13,57 \mathrm{~b}$ \\
P7 (tanah : cocopeat 2:1) & $11,08 \mathrm{~b}$ & $13,59 \mathrm{~b}$ \\
P1 (tanah) & $11,67 \mathrm{c}$ & $13,62 \mathrm{c}$ \\
\hline
\end{tabular}

Keterangan: setiap huruf yang berbeda menunjukkan adanya perbedaan yang nyata menurut uji BNJ taraf $5 \%$ 
sudah memiliki sistem perakaran yang telah terbentuk dengan sempurna. Sesuai dengan pernyataan Foth (1991) dalam Laing (2012) bahwa kemampuan suatu tanaman untuk menyerap unsur hara dari dalam media tanam akan meningkat jika sistem perakaran dan percabangan akarnya semakin besar.

Dari seluruh parameter pertumbuhan dan hasil bunga yang diamati, media tanam tanah memberikan nilai tertinggi dibandingan perlakuan media tanam yang lainnya. Menurut Harjadi (2002), faktor yang paling utama dalam pertumbuhan tanaman adalah media tanam yang dapat menyediakan unsur hara, karena dengan adanya unsur hara yang cukup dan tersedia bagi tanaman akan dapat meningkatkan proses metabolisme di dalam tubuh tanaman. Dari hasil analisis NPK tersedia menunjukkan bahwa unsur NPK tersedia yang paling besar dihasilkan oleh media tanam tanah yang dicampur dengan cocopeat dengan perbandingan 1:2 (P6). Walaupun jumlah NPK tersedia paling banyak berada di P6 (tanah : cocopeat 1:2) tetapi dari semua parameter pengamatan, perlakuan media tanam yang memberikan hasil tertinggi adalah P1 (tanah). Hal ini karena cocopeat diketahui banyak mengandung zat tanin yang dapat menghambat pertumbuhan tanaman, sesuai dengan teori Sukarman dkk (2012) yang menyatakan bahwa penyebab rendahnya respon pertumbuhan tanaman yang diberikan penambahan bahan cocopeat adalah adanya zat tanin yang terkandung dalam serbuk sabut kelapa. Zat tanin merupakan senyawa penghalang mekanis dalam penyerapan unsur hara. Sedangkan arang sekam mempunyai poripori yang besar dan menyebabkan proses kehilangan air lebih cepat dimana kadar air P3 adalah $18.48 \%$, sehingga proses metabolisme akan menjadi terhambat dan perkembangan vegetatif tanaman tidak dapat berlangsung secara maksimal, sesuai dengan pendapat Onggo et al., (2017) yang menyatakan bahwa penambahan arang sekam pada media tanam seharusnya memberikan keuntungan terhadap tanaman karena sifat arang sekam yang porous dapat memperbaiki sifat fisik media tanam tetapi karena sifatnya tersebut membuat media tidak mampu menyimpan air terlalu banyak sehingga tanaman dapat mengalami kekurangan air yang dapat mengganggu pertumbuhan dan perkembangan tanaman.

\section{KESIMPULAN}

Berdasarkan hasil penelitian ini maka dapat disimpulkan bahwa komposisi media tanam tidak berpengaruh nyata pada pertumbuhan tanaman gladiol yaitu tinggi daun dan jumlah daun tetapi berpengaruh nyata terhadap hasil bunga yaitu jumlah bunga dan diameter bunga. Perlakuan media tanam yang memberikan kualitas bunga paling baik dibandingkan dengan perlakuan media tanam yang lainnya adalah P1 (tanah) dengan jumlah bunga 11,67 kuntum dan diameter bunga $13,62 \mathrm{~cm}$, sedangkan perlakuan media tanam yang memberikan kualitas bunga paling rendah adalah P3 (tanah : arang sekam perbandingan $1: 2$ ) dengan jumlah bunga 10 kuntum dan diameter bunga $13,03 \mathrm{~cm}$.

\section{DAFTAR PUSTAKA}

Agustin, A. D., M. Riniarti., Duryat. 2014. Pemanfaatan limbah serbuk gergaji dan arang sekam sebagai media sapih untuk cempaka kuning (Michelia champaca). Jurnal Sylva Lestari 2 (3): 49-58.

Badriah, D. S. 2007. Budidaya Gladiol. Departemen Pertanian. Jakarta.

Balitbang Pertanian. 2014. Budidaya Bunga Gladiol Menjanjikan. http:// www.litbang.pertanian.go.id/berita/one/ 1738/.

Balai Penelitian Tanah. 2009. Petunjuk Teknis [edisi 2] Analisis Kimia Tanah, tanaman, air dan pupuk. Departemen Pertanian. Bogor.

Direktorat Jenderal Hortikultura. 2015. Statistik Produksi Hortikultra Tahun 2014. Kementerian Pertanian. Jakarta.

Harjadi, S. S. 2002. Pengantar Agronomi. Gramedia. Jakarta. 
Irawan, A., Y. Kafiar. 2015. Pemanfaatan cocopeat dan arang sekam padi sebagai media tanam bibit cempaka wasian (Elmerrilia ovalis). Prosiding Seminar Nasional masyarakat Biodiversitas Indonesia 1 (2): 805-808.

Istomo., Valentino, N. 2012. Pengaruh Perlakuan Kombinasi Media Terhadap Pertumbuhan Anakan Tumih (Combretocarpus rotundatus (Miq.) Danser). Jurnal Silvikultur Tropika 3 (2): 81-84.

Jabbar, A., A. Tahranifar., M. Shuor., S. H. Nemati. 2018. Effect of Different Media on Some Growth, Flowering and Biochemical Parameters of Two Cultivars of Gladiolus (Gladiolus grandiflorus L.) under Soilless Conditions. Journal of Ornamental Plants 8(3): 205-215.

Kusmarwiyah, R., S. Erni. 2011. Pengaruh media tumbuh dan pupuk organik cair terhadap pertumbuhan dan hasil tanaman seledri (Apium graveolens L.). Jurnal Ilmiah Budidaya Pertanian 4 (2): 7-12.

Laing, Y., T. Nugrahini., Mahdalena. 2012. Respon Pertumbuhan dan Hasil Tanaman Bunga Gladiol (Gladiolus hibridus) Terhadap Penggunaan Media Tanam dan Pupuk Saputra Nutrien. Jurnal Agrifarm 1 (1):1623.

Malik, N. 2015. Pertumbuhan Jumlah Daun Tanaman Sambiloto (Andrographis paniculata. Ness) Hasil Pemberian Pupuk dan Intensitas Cahaya Matahari yang Berbeda. Biowallacea 2(1):126-135.

Onggo, T. M., Kusumiyati, A., Nurfitriana. 2017. Pengaruh penambahan arang sekam dan ukuran polybag terhadap pertumbuhan dan hasil tanaman tomat kultivar 'Valouro' hasil sambung batang. Jurnal Kultivasi 16(1):298-304. 